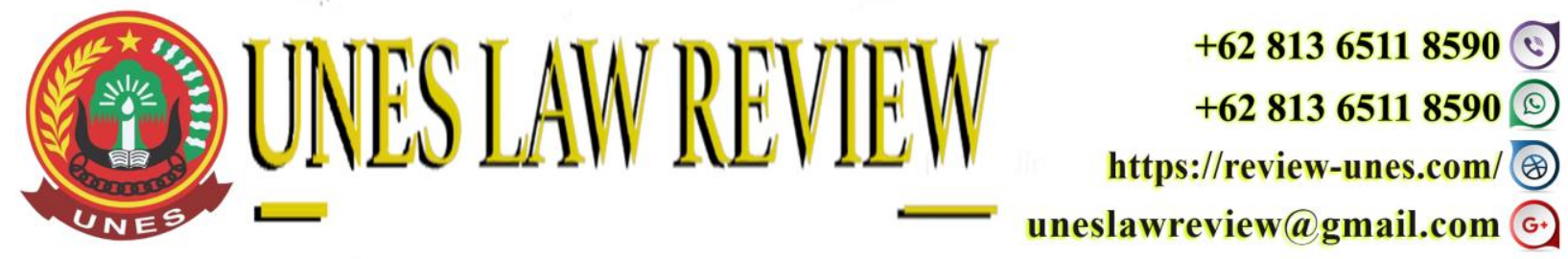

DOI: https://doi.org/10.31933/unesrev.v3i4

Diterima: 20/07/2021, Diperbaiki: 27/07/2021, Diterbitkan: 01/08/2021

\title{
PENGATURAN PENGAWASAN LALU LINTAS BARANG KENA CUKAI PADA KAWASAN PERDAGANGAN BEBAS (Studi Pencabutan Fasilitas Cukai Pada Kawasan Perdagangan Bebas)
}

\section{Arif Budiman}

Program Magister Ilmu Hukum, Fakultas Hukum, Universitas Ekasakti, Padang, Indonesia.

Email: dudy_sriyono@yahoo.com

Corresponding Author: Arif Budiman

\section{ABSTRACT}

Based on Article 17 section (2) of Government Regulation Number 10 of 2012 Excisable Goods in Free Trade Zone (FTZ) can be granted exemption. However, after the issuance of Government Regulation Number 41 of 2021 the duty-free facility is revoked, the Excisable Goods in FTZ is charged to excise duty. Formulation of the problem in this thesis is how to regulate and supervise the excisable goods traffic at the FTZ and how to implicate the juridical of the official note issued by the Director General of Customs and Excise regarding the Revocation of DutyFree Facilities at the FTZ. This is a legal research with descriptive specifications. The approach used is a normative juridical approach. It is used secondary data collected through literature research and analyzed the data qualitatively to be presented in a qualitative descriptive form. Based on the results of the study, it is known that the Regulation of the Traffic of Excisable Goods at the FTZ in Indonesia before the Memorandum of the Directorate General of Customs and Excise number 466/BC/2019 used the CK-FTZ document. Following the Government Regulation Number 41 of 2021, the arrangement was the same as the excise document in other customs areas. The supervision of the traffic of excisable goods at the FTZ in Indonesia carried out by DJBC is a form of prevention and repressive (action). The Juridical Implications of the Official Memorandum number ND-466/BC/2019 revoke the duty-free facility at the FTZ indirectly. Government Regulation Number 41 of 2021 has been issued to answer the Official Memorandum, but it is necessary to review it if it is related to the above regulation, Law Number 44 of 2007 so that in the formation of a legislation in accordance with the hierarchy and in line "lex superior" principle. derogat legi inferior".

Keywords: Judges' Considerations, Criminal Decisions, Field Trials, Corruption 


\section{ABSTRAK}

Berdasarkan Pasal 17 ayat (2) Peraturan Pemerintah Nomor 10 Tahun 2012 Barang Kena Cukai di Kawasan Perdagangan Bebas (FTZ) dapat diberikan pembebasan. Namun, setelah diterbitkannya Peraturan Pemerintah Nomor 41 Tahun 2021 fasilitas bebas bea tersebut dicabut, Barang Kena Cukai di FTZ dikenakan cukai. Rumusan masalah dalam skripsi ini adalah bagaimana pengaturan dan pengawasan lalu lintas barang kena cukai di FTZ dan bagaimana implikasi yuridis dari nota dinas yang dikeluarkan oleh Dirjen Bea dan Cukai tentang Pencabutan Fasilitas Bebas Bea di FTZ . Penelitian ini merupakan penelitian hukum dengan spesifikasi deskriptif. Pendekatan yang digunakan adalah pendekatan yuridis normatif. Data yang digunakan adalah data sekunder yang dikumpulkan melalui penelitian kepustakaan dan dianalisis secara kualitatif untuk disajikan dalam bentuk deskriptif kualitatif. Berdasarkan hasil penelitian diketahui bahwa Pengaturan Lalu Lintas Barang Kena Cukai di FTZ di Indonesia sebelum Memorandum Ditjen Bea dan Cukai nomor 466/BC/2019 menggunakan dokumen CK-FTZ. Sesuai Peraturan Pemerintah Nomor 41 Tahun 2021, pengaturannya sama dengan dokumen cukai di daerah pabean lainnya. Pengawasan lalu lintas barang kena cukai di FTZ di Indonesia yang dilakukan DJBC merupakan bentuk pencegahan dan represif (penindakan). Implikasi Yuridis Nota Resmi nomor ND-466/BC/2019 mencabut fasilitas bebas bea di FTZ secara tidak langsung. Peraturan Pemerintah Nomor 41 Tahun 2021 telah dikeluarkan untuk menjawab Memorandum Dinas, namun perlu ditinjau kembali jika dikaitkan dengan peraturan di atas, Undang-Undang Nomor 44 Tahun 2007 agar dalam pembentukan peraturan perundangundangan sesuai dengan hierarki dan sejalan dengan prinsip "lex superior". derogat legi inferior".

Kata Kunci: Pencabutan, Fasilitas, Cukai, Kawasan Perdagangan Bebas

\section{PENDAHULUAN}

Kawasan Perdagangan Bebas merupakan salah satu bentuk dari zona ekonomi (Economic Zone) pada umumnya memiliki pengertian yang cukup beragam. Hal ini diduga sebagai akibat adanya perbedaan dalam sudut pandang para ahli tentang konsep Kawasan Perdagangan Bebas. Perdagangan Bebas (free trade) adalah konsep teoritis yang mengandaikan berlakunya sistem perdagangan internasinal yang dibebaskan dari hambatan yang disebabkan oleh ketentuan pemerintah suatu negara, baik yang disebabkan oleh pengenaan tarif (tariff barriers) maupun nir tarif (bukan tarif/ non tariff barriers) (Heri Muliono, 2001:117-118). Menurut Charles W Thurston Kawasan Perdagangan Bebas (Free Trade Zone) adalah:

"An Free Trade Zone is in essence, a tax free enclave and not consideres part of the country as far as import regulations are concernen. When an item leaves an free trade zone and is officially imported into the host country of the Free Trade Zone, all duties and regulation are imposed" (Capela and Hatman dalam Burmansyah Edy, 2009).

Menurut Syarif Hidayat (2010:56) Kawasan Perdagangan Bebas atau Free Trade Zone

(FTZ) didefinisikan sebagai : Suatu kawasan yang berada dalam wilayah hukum Negara Kesatuan Republik Indonesia yang terpisah dari daerah pabean, sehingga bebas dari pengenaan bea masuk, pajak pertambahan nilai (PPN), PPnBM dan Cukai. 
Pada tahun 2000 pemerintah Republik Indonesia mengeluarkan Peraturan Pemerintah Pengganti Undang-Undang (Perpu) Nomor 1 Tahun 2000 sebagaimana ditetapkan sebagai Undang-Undang Nomor 36 Tahun 2000 Tentang Kawasan Perdagangan Bebas dan Pelabuhan Bebas. Menurut Pasal 1 Ayat (1) disebutkan bahwa: Kawasan Perdagangan Bebas dan Pelabuhan Bebas adalah suatu kawasan yang berada dalam wilayah hukum Negara Kesatuan Republik Indonesia yang terpisah dari daerah pabean sehingga bebas dari pengenaan Bea Masuk, Pajak Pertambahan Nilai, Pajak Penjualan atas Barang Mewah, dan Cukai.”

Menurut penelusuran dari peraturan perundang-undangan, pada tahun 2021 terdapat 4 (empat) wilayah di Indonesia yang termasuk daerah Kawasan Perdagangan Bebas, yaitu:

1. Kawasan Perdagangan Bebas (FTZ) Sabang yang dibentuk kembali dengan UndangUndang Nomor 37 Tahun 2000 tentang Penetapan Peraturan Pemerintah Pengganti Undang-Undang Nomor 2 Tahun 2000 Tentang Kawasan Perdagangan Bebas Dan Pelabuhan Bebas Sabang Menjadi Undang-Undang.

2. Kawasan Perdagangan Bebas Batam, dibentuk berdasarkan Peraturan Pemerintah (PP) Nomor 46 Tahun 2007 juncto PP Nomor 62 Tahun 2019.

3. Kawasan Perdagangan Bebas Bintan, dibentuk berdasarkan PP Nomor 47 Tahun 2007 juncto PP Nomor 41 Tahun 2017.

4. Kawasan Perdagangan Bebas Karimun, dibentuk berdasarkan PP Nomor 48 Tahun 2007 joncto PP Nomor 40 Tahun 2017.

Cukai merupakan pembebanan pungutan negara yang dikenakan hanya terhadap pemakaian barang-barang tertentu saja di dalam daerah pabean. Pada saat ini cukai yang dikelola oleh DJBC yaitu cukai atas hasil tembakau, seperti cigaret, cerutu, rokok daun, tembakau iris dan hasil pengolahan tembakau lainnya; cukai atas minuman yang mengandung etil alkohol dalam kadar berapapun; serta cukai atas etil alkohol atau etanol (Adrian Sutedi, 2012:147). Berdasarkan Pasal 1 ayat (1) Undang-Undang Nomor 11 Tahun 1995 juncto Undang-Undang Nomor 39 Tahun 2007 tentang Cukai, "Cukai adalah Pungutan negara yang dikenakan terhadap barangbarang tertentu yang mempunyai sifat atau karakteristik yang ditetapkan dalam undang-undang cukai" merupakan penerimaan negara guna mewujudkan kesejahteraan bangsa.

Seiring berjalannya waktu dan perkembangannya, terdapat permasalah-permasalahan dalam pelaksanaan Kawasan Perdagangan Bebas antara lain: Pertama, sulitnya mencapai tujuan yang menjadi skema Kawasan Perdagangan Bebas itu sendiri, salah satunya mengenai pengaturan lalu lintas barang kena cukai di Kawasan Perdagangan Bebas. Kedua, sulitnya melakukan pengawasan dan penegakan hukum terhadap barang-barang eks Kawasan Perdagangan Bebas termasuk barang kena cukai yang terlanjur keluar ke dalam daerah pabean tanpa diawasi oleh petugas DJBC di Kawasan Perdagangan Bebas. Ketiga, adanya penyalahgunaan wewenang, sehingga terjadi kebocoran terhadap penerimaan negara yang sangat dibutuhkan untuk membiayai jalannya roda pemerintahan.

Seiring berjalannya waktu Komisi Pemberantasan Korupsi (KPK) melakukan Kajian terkait Optimalisasi Penerimaan Negara di Kawasan Perdagangan Bebas dan Pelabuhan Bebas. Berdasarkan kajian tersebut KPK mengeluarkan rekomendasi berdasarkan surat Ketua KPK 
Nomor B-1744/LIT.05/01-16/02/2009 tanggal 15 Februari 2019 kepada Presiden Republik Indonesia mengenai rekomendasi perbaikan kebijakan Kawasan Perdagangan Bebas dan Pelabuhan Bebas. Menindaklanjuti surat rekomendasi dari Ketua KPK tersebut, Kementerian Koordinator Bidang Perekonomian mengirimkan surat kepada Direktur Jenderal Bea dan Cukai melalui surat Nomor IPW.4.3-231/SES.M.EKON/05/2019 tanggal 9 Mei 2019 Perihal Tindak Lanjut Rekomendasi Komisi Pemberantasan Korupsi (KPK) Atas Hasil Kajian Optimalisasi Penerimaan Negara Di Kawasan Perdagangan Bebas dan Pelabuhan Bebas (KPBPB) Tahun 2018 Terkait Pencabutan Fasilitas Cukai di KPBPB. Surat Menteri Koordinator Bidang Perekonomian ditindaklanjuti Direktur Jenderal Bea dan Cukai dengan mengeluarkan Nota Dinas Nomor 466/BC/2019 tanggal 14 Mei 2019 Hal Penghentian Pelayananan Dokumen CKFTZ yang ditujuan kepada Para Kepala Kantor Pelayanan Utama (KPU) Bea dan Cukai dan Para Kepala Kantor Pengawasan dan Pelayanan (KPPBC) Bea dan Cukai di Indonesia.

Sejak diterbitkan nota dinas tersebut, ramai pemberitaan dimedia masa maupun media sosial dimana dalam pemberitaan tersebut disebutkan bahwa sejak Rabu 17 Mei 2019 pemerintah resmi mencabut ketentuan bebas cukai untuk produk konsumsi rokok dan minuman mengandung etil alkohol di 4 (empat) zona perdagangan bebas (Free Trade Zone) di Indonesia yaitu Batam, Bintan, Karimun (Kepulauan Riau), dan Sabang di Nanggroe Aceh Darussalam.

Berdasarkan latar belakang yang diuraikan diatas, maka permasalahan yang akan dibahas adalah bagaimana Pengaturan dan Pengawasan Lintas Barang Kena Cukai Pada Kawasan Perdagangan Bebas serta bagaimana Implikasi Yuridis Nota Dinas yang dikeluarkan oleh Direktur Jenderal Bea dan Cukai terkait Pencabutan Fasilitas Bebas Cukai Pada Kawasan Perdagangan Bebas di Indonesia?

\section{METODE PENELITIAN}

Spesifikasi penelitian adalah deskriptif analitis, dengan menggunakan pendekatan Yuridis Normatif. Jenis data yang digunakan adalah data sekunder di peroleh dari studi dokumen dan studi kepustakaan. Data yang diperoleh dianalisa secara kualitatif dan disajikan dalam bentuk deskriptif kualitatif.

\section{HASIL DAN PEMBAHASAN}

\section{Pengaturan Lalu Lintas Barang Kena Cukai Pada Kawasan Perdagangan Bebas.}

Kawasan Perdagangan Bebas adalah kawasan yang diberikan keistimewaan berupa fasilitas dalam pelaksanaan perdagangan internasional yang diterapkan di Wilayah Negara Kesatuan Republik Indonesia (Daerah Pabean) yang dianggap atau diperlakukan sebagai luar daerah pabean. Pengaturan lalu lintas Barang Kena Cukai yang masuk dan keluar Kawasan Perdagangan Bebas merupakan hal yang sangat penting untuk dilakukan agar tujuan penerapan pemberian fasilitas pada skema FTZ dapat tercapai sesuai sasaran.

Dokumen Cukai Free Trade Zone yang disingkat dengan CK-FTZ adalah dokumen cukai untuk pemberitahuan dalam rangka pemasukan barang kena cukai ke Kawasan Bebas atau pengeluaraan Barang Kena Cukai dari Kawasan Bebas, dalam bentuk formulir atau melalui 
media elektronik. Adapun dokumen CK-FTZ yang digunakan untuk melindungi pengangkutan Barang Kena Cukai yaitu berupa:

1. Barang Kena Cukai berupa Minuman Mengandung Etil Alkohol yang belum dilunasi cukainya yang berasal dari Pabrik di Tempat Lain Dalam Daerah Pabean untuk dimasukkan ke Kawasan Bebas;

2. Barang Kena Cukai berupa Etil Alkohol yang belum dilunasi cukainya yang berasal dari Pabrik di Kawasan Bebas ke Tempat Lain Dalam Daerah Pabean atau Kawasan Bebas lainnya;

3. Barang Kena Cukai berupa Minuman Mengandung Etil Alkohol yang dikeluarkan dari Pabrik di Kawasan Bebas untuk konsumsi penduduk di Kawasan Bebas yang bersangkutan atau ke Kawasan Bebas lainnya; dan/atau

4. Barang Kena Cukai berupa Etil Alkohol atau Minuman Mengandung Etil Alkohol yang sudah dilunasi cukainya yang dikeluarkan dari Pabrik di Kawasan Bebas ke Tempat Lain Dalam Daerah Pabean.

Pemasukan Barang Kena Cukai ke Kawasan Perdagangan Bebas dan Pelabuhan Bebas dari Luar Daerah Pabean hanya dapat dilakukan oleh Pengusaha yang telah mendapatkan izin usaha dari Badan Pengusahaan Kawasan. Pemasukan BKC tersebut wajib dilakukan melalui Kawasan Pabean dalam pelabuhan atau bandar udara yang ditunjuk oleh Badan Pengusahaan Kawasan. Terhadap jumlah dan jenis BKC yang dimasukan sebagai barang konsumsi untuk kebutuhan penduduk di Kawasan Bebas ditetapkan oleh Badan Pengusahaan Kawasan.

Pengeluaran Barang Kena Cukai dari Pabrik di Kawasan Bebas ke Tempat Lain Dalam Daerah Pabean (TLDDP) wajib dilunasi cukainya sesuai ketentuan peraturan perundangundangan yang mengatur tentang pelunasan cukai, kecuali terhadap BKC yang mendapatkan fasilitas tidak dipungut cukai atau pembebasan cukai. Pengeluaran BKC berupa Etil Alkohol (EA) dan Minuman Mengandung Etil Alkohol (MMEA) dari Pabrik di Kawasan Bebas atau ke Kawasan Bebas lainnya masih terutang cukai sampai dengan BKC tersebut selesai dimasukkan ke Kawasan Bebas lainnya.

Pengaturan lalu lintas barang kena cukai pada kawasan perdagangan bebas di Indonesia bila dikaitkan dengan teori kewenangan merupakan atribusi yang diberikan oleh negara kepada Direktorat Jenderal Bea dan Cukai. Sebelum adanya Nota Dinas Dirjen Bea dan Cukai Nomor 466/BC/2019 pengaturan tentang cukai di Kawasan Bebas mengacu pada Undang-Undang Nomor 44 tahun 2007 dan pasal 17 ayat (2) Peraturan Pemerintah Nomor 10 tahun 2012 bahwa pemasukan barang kena cukai untuk kebutuhan konsumsi di Kawasan Perdagangan Bebas dan Pelabuhan Bebas "dapat" diberikan pembebasan cukai. Jadi pada Kawasan Perdagangan Bebas diberikan fasilitas bebas cukai. Sedangkan setelah adanya Nota Dinas, maka pengaturan barang kena cukai di Kawasan Perdagangan Bebas mengacu pada Undang-Undang Nomor 39 Tahun 2007 dan Peraturan Pemerintah Nomor 41 tahun 2021, karena pada Kawasan Perdagangan Bebas tidak diberikan lagi fasilitas bebas cukai.

Guna menjamin dan mengontrol Barang Kena Cukai yang dikirim dari luar daerah pabean, atau tempat lain dalam daerah pabean atau dari Kawasan Perdagangan Bebas lainnya ke FTZ, 
maka digunakan dokumen CK-FTZ sebagai dokumen kontrolnya. Sebelum adanya Nota Dinas Nomor 466/BC/2019 Semua pelayanan terkait lalu lintas barang kena cukai di Kawasan Perdagangan Bebas menggunakan dokumen CK-FTZ, sementara sejak dikeluarkannya Nota Dinas Nomor 466/BC/2019, maka pelayanan dokumen CK-FTZ pada Kawasan Perdagangan Bebas dihentikan. Setelah dikeluarkannya Nota Dinas Dirjen Bea Cukai Nomor 466/BC/2019, sejak tanggal 17 Mei 2019 pelayanan Barang Kena Cukai pada Kawasan Pedagangan Bebas disamakan dengan pelayanan Barang Kena Cukai yang dilakukan dengan daerah pabean lainnya di Indonesia.

\section{Pengawasan Lalu Lintas Barang Kena Cukai Pada Kawasan Perdagangan Bebas.}

Pengawasan lalu lintas Barang Kena Cukai pada Kawasan perdagangan bebas bila dikaitkan dengan teori pengawasan merupakan dasar Direktorat Jenderal Bea dan Cukai dalam melaksanakan fungsi pengawasan, salah satunya yaitu pengawasan kepabeanan untuk semua jenis barang yang masuk ataupun keluar ke dan dari daerah pabean. Pemasukan barang ke daerah pabean dapat berasal dari: 1) kawasan FTZ yang ada di Indonesia, 2) negara yang terlibat perjanjian FTA dengan Indonesia, dan 3) negara lain. Asal barang ini disebut dengan luar daerah pabean atau dianggap sebagai luar daerah pabean dan kegiatan pemasukan barang ini disebut dengan istilah impor.

Seperti halnya pemasukan ke dalam daerah pabean, pengeluaran barang dari daerah pabean juga dapat ditujukan ke: 1) negara yang terlibat perjanjian FTA dengan Indonesia, 2) kawasan FTZ yang ada di Indonesia, dan 3) negara lain. Kegiatan pengeluaran barang ini disebut dengan istilah ekspor. Frasa "tanpa memperhatikan terutang bea dan pajak atau tidak" pada norma di atas, dapat diartikan bahwa dalam melakukan pengawasan Bea Cukai tidak melihat status barang apakah masih terutang pungutan negara atau tidak. Hal ini dikarenakan pada prinsipnya pengawasan kepabeanan adalah untuk memastikan terlaksananya semua formalitas/kewajiban pabean atas barang tersebut. Dengan demikian, tidak ada perbedaan sistem pengawasan antara barang yang masih terutang pungutan negara dengan yang tidak pada aktivitas impor dan ekspor ini.

Lalu lintas barang antar kawasan FTZ juga harus memenuhi kewajiban sesuai dengan dengan ketentuan dalam Undang-Undang Kepabeanan. Pengaturan mengenai praktik lalu lintas barang antar kawasan FTZ ini diperlukan agar memenuhi kewajiban pabean menurut penulis setidaknya didasarkan atas empat hal, yaitu:

1. Barang yang dikirim antar kawasan FTZ tersebut masih terutang hak-hak keuangan negara.

2. Barang yang dikirim dari suatu kawasan FTZ terlebih dahulu akan memasuki daerah pabean baru kemudian masuk ke kawasan FTZ lain, maka pelaksanaannya mengikuti ketentuan pengangkutan barang sesuai Undang-Undang Kepabeanan.

3. Untuk memastikan jalur pengangkutan barang-barang antar kawasan FTZ tersebut sesuai dengan jalur yang telah ditetapkan, diperlukan pengawasan kepabeanan.

4. Untuk mencegah terjadinya penyelundupan barang impor maupun ekspor dengan menggunakan modus pengiriman antar kawasan FTZ tersebut. 
Lalu lintas barang antar kawasan FTZ itu sendiri, menilik uraian di atas, erat kaitannya dengan pihak yang menyediakan jasa pengangkutan barang. Sistem pengawasan yang diterapkan terhadap lalu lintas barang pada kawasan FTZ ini dilaksanakan dengan efektif dan efisien sehingga tidak menghambat arus lalu lintas barang sehingga penerapan skema FTZ tepat sasaran dan sesuai dengan tujuan pembentukannya. Hal ini terlihat dengan adanya syarat dalam penerapan sistem pengawasan kepabeanan ini yang harus menggunakan manajemen risiko. Pengawasan kepabeanan yang dilaksanakan terhadap kawasan FTZ hanya terbatas pada mengawasi proses lalu lintas barang yang masuk dan keluar kawasan FTZ saja, tidak lebih. Hal ini sama dengan pengawasan kepabeanan yang diterapkan dalam mengawasi lalu lintas barang impor maupun ekspor yang melintasi batas negara secara konkret.

Terkait penerapan pengawasan kepabeanan terhadap aturan larangan pembatasan atas pemasukan barang yang langsung dari luar negeri (luar daerah pabean) ke kawasan FTZ, hanya terbatas pada barang yang menyangkut:

1. Kepentingan publik yang meliputi: moralitas atau ketertiban publik, keamanan publik, kebersihan umum atau kesehatan, atau atas pertimbangan dokter hewan atau phytosanitary; atau

2. Kepentingan dalam perlindungan hak paten, merek dagang dan hak cipta.

Luasnya wilayah yang ditetapkan sebagai Kawasan Perdagangan Bebas dan Pelabuhan Bebas juga membutuhkan pola pengawasan yang efektif dengan melihat kondisi yang ada. Adapun kondisi yang diperhitungkan terkait dengan lingkup pengawasan DJBC adalah:

1. Kondisi geografis KPBPB berupa kepualauan dan berjarak relatif dekat dengan Singapura dan Malaysia;

2. Cukup banyaknya pulau-pulau di wilayah provinsi Kepulauan Riau;

3. Adanya pemukiman penduduk serta pusat perbelanjaan dalam KPBPB;

4. Adanya pengangkutan barang dan penumpang antarpulau dan dalam lingkungan KPBPB;

5. Kemungkinan KPBPB dijadikan tempat penimbunan barang-barang yang terkena ketentuan pembatasan impor, seperti prekusor;

6. Banyaknya Pelabuhan khusus milik perusahaan shipyard dan Pelabuhan rakyat disepanjang pulau Batam;

7. Cukup banyaknya industri di pulau Batam yang terdiri atas beberapa perusahaan yang berbeda jenis usaha, nama perusahaan atau pemilik perusahaan;

8. Potensi pengangkutan barang dari KPBPB ke daerah pabean Indonesia lain secara illegal;

Berdasarkan hal-hal tersebut, guna melakukan pengawasan terhadap pemasukan dan pengeluaran barang ke dan dari KPBPB serta pencegahan kemungkinan terjadinya pengangkutan barang dari KPBPB ke daerah lain dalam daerah pabean Indonesia, maka kegiatan pengawasan yang menjadi tanggung jawab Direktorat Jenderal Bea dan Cukai terhadap Barang Kena Cukai di Kawasan Perdagangan Bebas dapat dilakukan dalam berbagai upaya yaitu preventif dan represif.

1. Preventif (Pencegahan) 
Merupakan upaya yang dilakukan untuk tujuan pencegahan sebelum adanya pelanggaran di bidang cukai. Kegiatan Pengawasan secara preventif biasa dilakukan dengan beberapa kegiatan antara lain:

a. Penyuluhan dan Pembinaan Hukum, seperti sosialisasi peraturan Kawasan bebas, sosialisasi peraturan tentang kepabeanan dan cukai kepada masyarakat, pengusaha, pedagang dan aparat penegak hukum lainnya

b. Surveilance oleh tim Intelijen, seperti pengumpulan informasi terkait peredaran barang kena cukai illegal dan tempat-tempat dilakukan pemuatan atau pengeluaran barang-barang illegal.

c. Patroli, baik darat maupun patroli laut dengan menggunakan kapal patrol bea dan cukai dan patroli bersama dengan penegak hukum lainnya.

\section{Represif (Penindakan)}

Merupakan bentuk kegiatan yang dilakukan setelah pengawasan prefentif. Adapun kegiatan dalam bentuk represif adalah :

a. Penangkapan

Penangkapan adalah suatu tindakan penyidik berupa pengekangan sementara waktu kebebasan tersangka atau terdakwa apabila terdapat cukup bukti guna kepentingan penyidikan atau penuntutan dan/atau peradilan dalam hal serta menurut cara yang diatur dalam undang-undang.

b. Penyitaan atau Penegahan

Berdasarkan Pasal 1 ayat 16 Undang-Undang Nomor 8 tahun 1981 penyitaan adalah "serangkaian tindakan penyidik untuk mengambil alih dan/atau menyimpan di bawah pengawasannya benda bergerak atau tidak bergerak, berwujud atau tidak berwujud, untuk kepentingan pembuktian dalam penyidikan, penuntutan dan peradilan”.

c. Operasi Pasar

Operasi pasar adalah suatu tindakan secara represif yang dilakukan oleh Bea dan Cukai sebagai wujud pengawasan dan penindakan terhadap pelanggaran baik administrasi maupun pidana. Operasi pasar dilakukan secara berkala oleh pegawai bea dan cukai di pasar-pasar, warung-warung, toko-toko guna untuk memastikan kepatuhan dari para pedagang dalam menjual barang kena cukai yang legal dan untuk mengurangi peredaran barang kena cukai illegal dipasaran.

Dalam melaksanakan pengawasan di bidang cukai, dibutuhkan profesionalisme pegawaipegawai DJBC. Untuk menunjang profesionalisme, maka pegawai Bea dan Cukai harus mengetahui segala hal yang berhubungan dengan pelaksanaan peraturan perundang-undangan yang berlaku, terutama yang berhubungan dengan penyelesaian pelanggaran di bidang cukai, baik pelanggaran yang merugikan negara maupun pelanggaran yang termasuk tindak pidana di bidang cukai.

Pegawai Bea dan Cukai sebagai penegak hukum dibidang kepabeanan dan cukai, selain dituntut dalam pelayanan, akuntabilitas dan governance (tindakan, sikap yang baik, teliti dan hati-hati), juga mempertanggung jawabkan semua tindakan yang dilakukan berkaitan dengan 
jabatannya, guna mendapatkan citra yang baik di pandangan masyarakat terhadap kinerja Direktorat Jenderal Bea dan Cukai.

\section{Implikasi Yuridis Nota Dinas yang dikeluarkan oleh Direktur Jenderal Bea dan Cukai terkait Pencabutan Fasilitas Bebas Cukai Pada Kawasan Perdagangan Bebas di Indonesia}

Nota Dinas merupakan naskah dinas internal di lingkungan unit kerja yang dibuat oleh pejabat yang berwenang dalam rangka pelaksanaan tugas, fungsi dan tanggung jawab jabatan kedinasan yang ditujukan kepada pejabat lain di lingkungan internal unit organisasi yang bersangkutan guna menyampaikan laporan, pemberitahuan, pernyataan, permintaan atau penyampaian pendapat kepada pejabat lain. Nota dinas ini memuat hal yang bersifat rutin, berupa catatan ringkas dan lengkap, serta dapat langsung dijawab dengan disposisi oleh pejabat yang dituju. Namun nota dinas tidak boleh digunakan untuk membuat putusan mutasi pegawai. Nota dinas digunakan untuk komunikasi dari bawahan kepada atasan atau antar pejabat yang setingkat atau dari atasan kepada bawahan.

Nota Dinas yang dikeluarkan oleh Direktur Jenderal Bea dan Cukai Nomor 466/BC/2019 tanggal 14 Mei 2019 Hal Penghentian Pelayanan Dokumen CK-FTZ merupakan bentuk untuk menindaklanjuti Surat Menteri Koordinator Bidang Perekonomian Nomor IPW.4.3231/SES.M.EKON/05/2019 tanggal 9 Mei 2019 Perihal Tindak Lanjut Lanjut Rekomendasi Komisi Pemberantasan Korupsi (KPK) Atas Hasil Kajian Optimalisasi Penerimaan Negara Di Kawasan Perdagangan Bebas dan Pelabuhan Bebas (KPBPB) tahun 2018. Nota Dinas tersebut ditujukan kepada internal Bea dan Cukai dalam ha ini untuk Para Kepala Kantor Pelayanan Utama (KPU) dan Para Kepala Kantor Pengawasan dan Pelayanan Bea dan Cukai (KPPBC). Dengan dikeluarkannya nota dinas Nomor 466/BC/2019 tanggal 14 Mei 2019 oleh Direktur Jenderal Bea dan Cukai tersebut secara tidak langsung sudah mencabut fasilitas bebas cukai pada Kawasan Perdagangan Bebas yang selama ini diberikan oleh pemerintah berdasarkan Pasal 17 ayat (2) Peraturan Pemerintah Nomor 10 Tahun 2012 tentang kepabeanan perpajakan, dan cukai serta tata laksana pemasukan dan pengeluaran barang ke dan dari serta berada di kawasan yang telah ditetapkan sebagai kawasan perdagangan bebas dan pelabuhan bebas, mengatur bahwa pemasukan barang kena cukai untuk kebutuhan konsumsi di KPBPB "dapat" diberikan pembebasan cukai. Dengan demikian Peraturan Pemerintah ini terdapat celah kebijakan/ diskresi karena adanya kata-kata dapat bisa tidak mewajibkan pemberian pembebasan cukai, sehingga pengeluaran nota dinas yang mencabut secara tidak langsung fasilitas bebas cukai di FTZ tidak bertentangan dengan Peraturan Pemerintah Nomor 10 Tahun 2012

Berdasarkan nota dinas Direktur Jenderal Bea dan Cukai nomor ND-466/BC/2019 tanggal 14 Mei 2019 Hal Penghentian Pelayanan Dokumen CK-FTZ, maka pelayanan terhadap CK-FTZ sejak tanggal 17 Mei 2019 tidak dapat untuk dilayani, terhadap dokumen CK-FTZ sebelum tanggal tersebut masih dapat dilayani. Artinya setelah dikeluarkannya nota dinas tersebut peredaran barang kena cukai yang sebelumnya tidak dilekati pita cukai untuk konsumsi masyarakat di Kawasan Perdagangan Bebas sudah tidak berlaku lagi dan kedepannya peredaran 
barang kena cukai di Kawasan Perdagangan Bebas disamakan seperti daerah pabean lainnya dengan menggunakan pita cukai.

Adanya perbedaan harga yang cukup jauh antara barang kena cukai yang beredar di Kawasan Perdagangan Bebas dengan barang kena cukai yang berada di luar Kawasan Perdagangan Bebas mengakibatkan para oknum yang tidak bertanggungjawab untuk mencari keuntungan pribadi dengan cara menyelundupkan barang kena cukai yang ada pada Kawasan Perdagangan Bebas ke daerah pabean lainnya atau luar Kawasan Perdagangan Bebas. Hal ini sangat merugikan bagi para pengusaha-pengusaha rokok di dalam daerah pabean yang telah membayar cukai kepada negara dan juga mengakibatkan adanya kerugian terhadap penerimaan negara.

Pengeluran Nota Dinas Nomor 466/BC/2019 dinilai bertentangan dengan pasal 17 ayat (2) Peraturan Pemerintah Nomor 10 Tahun 2012 dan Undang-Undang Nomor 44 tahun 2007. Dimana dalam Peraturan Pemerintah Nomor 10 menyebutkan bahwa "dapat" diberikan pembebasan cukai. Langkah Dirjen Bea dan Cukai dalam mengeluarkan nota dinas tersebut merupakan upaya untuk mengatasi persoalan kongkret dalam menjalankan pemerintahan, guna untuk menindaklanjuti rekomendasi KPK kerana adanya penyalahgunaan wewenang dan kebocoran pada penerimaan negara.

Apabila kita lihat dari teori sistem perundang-undang berdasarkan Undang-Undang Nomor 12 tahun 2011 juncto Undang-Undang nomor 15 tahun 2019 tentang Aturan Hierarki Perundang-Undangan. Nota dinas yang dikeluarkan oleh Dirjen Bea Cukai merupakan Kebijakan/ diskresi yang bersifat bebas karena pada pada pasal 17 ayat (2) Peraturan Pemerintah nomor 10 tahun 2012 menyatakan "dapat" diberikan pembebasan cukai. Dimana pada aturan tersebut terdapat celah diskresi yang selama memberikan pilihan dikasih pembebasan atau tidak guna untuk mendukung dan menunjang kegiatan pada Kawasan Perdagangan Bebas.

Menurut Pasal 7 ayat (1) Undang-Undang Nomor 12 Tahun 2011 juncto Undang-Undang Nomor 15 Tahun 2019 tentang Pembentukan Peraturan Perundang-Undangan, jenis dan hierarki peraturan perundang-undangan terdiri atas:

Undang-Undang Dasar Negara Republik Indonesia Tahun 1945;

Ketetapan Majelis Permusyawaratan Rakyat

Undang-Undang/ Peraturan Pemerintah Pengganti Undang-Undang;

Peraturan Pemerintah;

Peraturan Presiden;

Peraturan Daerah Provinsi; dan

Peraturan Daerah Kabupaten/ Kota.

Kekuatan hukum dan kedudukan peraturan perundang-undangan sesuai dalam hierarki adalah tingkatan atau urutan setiap jenis peraturan perundang-undangan yang didasarkan pada asas bahwa peraturan perundang-undangan yang lebih rendah tidak boleh bertentangan dengan peraturan perundang-undangan yang lebih tinggi.

Berdasarkan uraian diatas bahwa Surat Edaran saja tidak termasuk ke dalam jenis peraturan perundang-undangan di Indonesia apalagi Nota Dinas. Nota Dinas bukan merupakan 
peraturan perundang-undangan (regeling), bukan juga keputusan tata usaha negara (beschikking) melainkan sebuah peraturan kebijakan (beleidsregel) atau peraturan perundang-undangan semu (pseudo wetgeving). Pembentukan setiap peraturan kebijakan tetap harus tunduk pada asas-asas pembentukan peraturan perundang-undangan dan peraturan kebijakan yang baik (beginselen van behoorlijke regelgeving). Peraturan kebijakan yang secara tidak langsung mengikat publik akan menimbulkan masalah jika pembentukannya tidak memenuhi asas pembentukannya tidak memenuhi asas pembentukan peraturan perundang-undangan baik formil maupun materil.

Peraturan kebijaksanan merupakan produk kebijakan yang bersifat bebas yang ditetapkan oleh pejabat-pejabat administrasi negara dalam rangka penyelanggaran tugas-tugas pemerintahan (Hotman P. Sibuea, 2010:101). Sifat lain dari peraturan kebijaksanaan adalah tidak mengikat hukum secara langsung, namun mempunyai relevansi hukum. Peraturan-peraturan kebijaksanaan memberi peluang bagaimana suatu badan tata usaha negara menjalankan kewenangan pemerintahan (beschiking bevoegdheeid). Hal ini sendiri harus dikaitkan dengan kewenangan pemerintahan atas dasar penggunaan descretionaire karena jika tidak demikian, maka tidak ada tempat bagi peraturan kebijaksanaan (Philipus M. Hadjon, 2002:152-153).

Seiring berjalannya waktu dalam melakukan penelitian tesis ini pada tanggal 2 Februari 2021 pemerintah mengeluaran Peraturan Pemerintah Nomor 41 Tahun 2021 tentang Penyelenggaraan Kawasan Perdagangan Bebas dan Pelabuhan Bebas serta mencabut Peraturan Pemerintah Nomor 10 Tahun 2012 tentang Perlakuan Kepabeanan, Perpajakan dan Cukai Serta Tata Laksana Pemasukan dan Pengeluaran Barang Ke dan Dari Serta Berada di Kawasan Perdagangan Bebas dan Pelabuhan Bebas. Peraturan Pemerintah Nomor 41 Tahun 2021 telah sejalan dengan apa yang akan disarankan oleh penulis dalam penelitian tesis ini yaitu meninjau kembali kata-kata "dapat" dalam pasal 17 ayat (2) Peraturan Pemerintah Nomor 10 Tahun 2012 agar dapat menjawab pertanyaan-pertanyaan terkait fasilitas cukai yang sudah diberikan selama ini pada Kawasan Perdagangan Bebas.

Apabila Peraturan Pemerintah Nomor 41 Tahun 2021 kita kaitkan dengan peraturan diatasnya yaitu UU Nomor 44 Tahun 2007 tentang Penetapan Peraturan Pemerintah Pengganti Undang-Undang Nomor 1 Tahun 2007 Tentang Perubahan Atas Undang-Undang Nomor 36 Tahun 2000 Tentang Penetapan Peraturan Pemerintah Pengganti Undang-Undang Nomor 1 Tahun 2000 tentang Kawasan Perdagangan Bebas dan Pelabuhan Bebas Menjadi UndangUndang Menjadi Undang-Undang. Berdasarkan Pasal 1 angka 1 disebutkan bahwa Kawasan Perdagangan Bebas dan Pelabuhan Bebas adalah suatu Kawasan yang berada dalam wilayah hukum Negara Kesatuan Republik Indonesia yang terpisah dari daerah pabean sehingga "bebas" dari pengenaan bea masuk, pajak pertambahan nilai, pajak penjualan atas barang mewah dan "cukai".

Mengacu pada peraturan dibawahnya, bahwa pada Pasal 61 Peraturan Pemerintah Nomor 41 tahun 2021 berbunyi :

1. Pemasukan Barang Kena Cukai dari Luar Daerah Pabean Ke KPBPB dikenai Cukai.

2. Barang Kena Cukai hasil produksi pabrik di KPBPB wajib dilunasi cukainya. 
3. Barang Kena Cukai hasil produksi di tempat lain dalam Daerah Pabean dapat dimasukan ke KPBPB dengan dilunasi cukainya.

4. Tata cara mengenai pelunasan cukai, penatausahaan, dan pengawasan Barang Kena Cukai sebagaimana dimaksud ayat (1), ayat (2) dan (3) dilaksanakan sesuai dengan ketentuan peraturan perundang-undangan mengenai cukai.

Berkenaan dengan hal tersebut diatas apabila kita kaji antara Undan-Undang dengan Peraturan Pemerintah terdapat perbedaan pandangan, dimana dalam Undang-Undang dikatakan bebas cukainya sementara pada Peraturan Pemerintah dikenai cukai atau wajib dilunasi cukainya.

Berdasarkan hal-hal tersebut diatas, bahwa untuk menjalankan suatu pemerintahan sesuai Pasal 5 ayat (2) UUD 1945 berbunyi "Presiden menetapkan peraturan pemerintah untuk menjalankan undang-undang sebagaimana mestinya. Apakah suatu peraturan perundangundangan sejalan dengan peraturan diatasnya maka Mahkamah Agung diberikan kewenangan untuk melakukan uji materi dari peraturan tersebut. Berdasarkan Pasal 24A ayat (1) UUD 1945 berbunyi "Mahkamah Agung berwenang mengadili pada tingkat kasasi, menguji peraturan perundang-undangan di bawah undang-undang dan mempunyai wewenang lainnya yang diberikan oleh undang-undang. Dalam melakukan kewenangannya berdasarkan Undang-Undang Nomor 5 Tahun 2004 tentang Perubahan Atas Undang-Undang nomor 14 Tahun 1985 Tentang Mahkamah Agung, dalam Pasal 31 ayat (1) dan ayat (2) berbunyi :

1. Mahkamah Agung mempunyai wewenang menguji peraturan perundang-undangan di bawah undang-undang terhadap undang-undang;

2. Mahkamah Agung menyatakan tidak sah peraturan perundang-undangan di bawah undangundang atas alasan bertentangan dengan peraturan perundang-undangan yang lebih tinggi atau pembentukan tidak memenuhi ketentuan yang berlaku;

Menurut penulis pemerintah sebaiknya meninjau kembali Peraturan Pemerintah Nomor 41 Tahun 2021 sebagaimana mencabut Peraturan Pemerintah Nomor 10 Tahun 2012 dengan peraturan perundang-undangan yang ada diatasnya yaitu Undang-Undang Nomor 44 Tahun 2007, karena untuk membentuk peraturan perundang-undangan yang baik harus terdapat kesesuaian jenis, hierarki, dan materi muatan. Dengan menilik kepada kata "hierarki", maka pengertian hierarki terkait peraturan perundang-undangan adalah tata urutan atau stratifikasi setiap jenis peraturan perundang-undangan yang didasarkan pada asas bahwa peraturan perundang-undangan yang lebih rendah tidak boleh bertentangan dengan peraturan perundangundangan yang lebih tinggi (lex superior derogat legi inferior).

\section{PENUTUP}

Pengaturan lalu lintas barang kena cukai pada kawasan perdagangan bebas di Indonesia adalah pengaturan yang dilakukan oleh Direktorat Jenderal Bea dan Cukai untuk mengontrol Barang Kena Cukai yang dikirim dari luar daerah pabean atau tempat lain dalam daerah pabean atau dari Kawasan Perdagangan Bebas lainnya ke FTZ. Pengaturan Pemasukan dan Pengeluaran Barang Kena Cukai sebelum adanya Nota Dinas Nomor 466/BC/2019 di Kawasan Perdagangan Bebas dengan menggunakan dokumen CK-FTZ. Setelah dikeluarkan Nota dinas dan Peraturan 
Pemerintah Nomor 41 Tahun 2021 pemasukan dan pengeluaran BKC pada Kawasan Perdagangan Bebas sama dengan dokumen cukai yang berlaku pada daerah pabean lainnya.

Pengawasan Barang Kena Cukai pada Kawasan Perdagangan Bebas di Indonesia dilakukan oleh Direktorat Jenderal Bea dan Cukai dalam bentuk kegiatan preventif (pencegahan) dan represif (penindakan). Pengawasan secara preventif meliputi kegiatan Penyuluhan, Pembinaan Hukum, Surveilance dan Patroli (darat dan laut). Sedangkan Pengawasan secara represif meliputi kegiatan penangkapan, penyitaan atau penegahan dan operasi pasar.

Implikasi yuridis penerbitan Penerbitan Nota Dinas oleh Direktur Jenderal Bea dan Cukai terkait pencabutan fasilitas bebas cukai pada Kawasan Perdagangan Bebas di Indonesia terhadap peredaran BKC di FTZ adalah dicabutnya fasilitas bebas cukai untuk konsumsi masyarakat yang selama ini ada FTZ. Isi dari Nota dinas tersebut bukan merupakan pencabutan fasilitas bebas cukai secara langsung pada FTZ akan tetapi perihal penghentian pelayanan dokumen CK-FTZ. Nota dinas yang dikeluarkan merupakan kebijakan/diskresi yang diambil oleh Direktur Jenderal Bea dan Cukai atas rekomendasi dari Komisi Pemberantasan Korupsi dan Menteri Koordinator Bidang Perekonomian karena adanya penyalahgunaan fasilitas bebas cukai yang diberikan selama ini di Kawasan Perdagangan Bebas, sehingga merugikan pada penerimaan negara dan pengusaha BKC dalam daerah pabean. Dengan dikeluarkan nota dinas tersebut secara tidak langsung mencabut fasilitas bebas cukai pada kawasan perdagangan bebas yang selama ini diberikan oleh pemerintah sesuai Pasal 17 ayat (2) Peraturan Pemerintah Nomor 10 Tahun 2012 mengatur bahwa pemasukan barang kena cukai untuk kebutuhan konsumsi di Kawasan Perdagangan Bebas dan Pelabuhan Bebas "dapat" diberikan pembebasan cukai. Peraturan Pemerintah ini tidak mewajibkan pemberian pembebasan cukai, sehingga nota dinas yang dikeluarkan Direktur Jenderal Bea dan Cukai tidak bertentangan dengan Peraturan Pemerintah Nomor 10 Tahun 2012 karena adanya kata "dapat" sehingga memberi ruang diskresi atau kebijakan oleh Direktur Jenderal Bea dan Cukai, dimana kebijakan/ diskresi tersebut bersifat bebas yang digunakan dalam rangka penyelanggaran tugas-tugas pemerintahan untuk menyelamatkan keuangan negara.

Diharapkan kepada semua stakeholder dan seluruh aparat pemerintah untuk mendukung berjalannya ketentuan-ketentuan di Kawasan Perdagangan Bebas termasuk bersama-sama melawan kecurangan maupun pelaggaran terhadap pemasukan barang dari dan ke kawasan perdagangan bebas termasuk barang kena cukai ilegal.

Ditetapkan suatu pulau yang terpisah dengan daratan atau keseluruhan wilayah dalam satu pulau merupakan Kawasan Perdagangan Bebas dan semua bentuk perizinan yang transparan dengan menggunakan teknologi informasi agar aparat yang berwenang mudah dalam melakukan pengawasan dan aturan-aturan tentang kawasan perdagangan bebas dapat diterapkan dengan baik.

Menurut penulis sebaiknya pemerintah mengkaji kembali antara Peraturan Pemerintah Nomor 41 Tahun 2021 dengan Undang-Undang Nomor 44 Tahun 2007, karena untuk membentuk peraturan perundang-undangan yang baik harus terdapat kesesuaian jenis, hierarki, dan materi muatan. 


\section{DAFTAR PUSTAKA}

Adrian Sutedi, Aspek Hukum Kepabeanan, Sinar Grafika, Jakarta 2012.

Capela and Hatman dalam Burmansyah Edy, "Pembentukan Kawasan Ekonomi Khusus (KEK) Dalam Pandangan Kelompok Masyarakat Sipil”, Seri kertas Kerja Institute For Global Justice (IGJ) 2009.

Heri Muliono “Merajut Batam Masa Depan Menyongsong Status Free Trade Zone”, Pustaka LP3ES Indonesia, Jakarta, 2001.

Hotman P. SIbuca, “Asas Negara Hukum, Peraturan Kebijakan”, Erlangga, Jakarta, 2010.

Philipus M. Hadjon, "Pengantar Hukum Administrasi Indonesia (Introduction to the Indonesia administrative Law)”, Gadjah Mada University Press, Yogyakarta, 2002.

Syarif Hidayat dan Agus Syarip Hidayat, Quo Vadis Kawasan Ekonomi Khusus (KEK), Rajawali Press, Jakarta, 2010.

Undang-Undang Dasar Negara Republik Indonesia Tahun 1945

Undang-Undang Nomor 5 Tahun 2004 tentang Perubahan Atas Undang-Undang nomor 14 Tahun 1985 Tentang Mahkamah Agung

Undang-Undang Nomor 44 Tahun 2007 tentang tentang Penetapan Peraturan Pemerintah Pengganti Undang-Undang Nomor 1 Tahun 2007 Tentang Perubahan Atas UndangUndang Nomor 36 Tahun 2000 Tentang Penetapan Peraturan Pemerintah Pengganti Undang-Undang Nomor 1 Tahun 2000 tentang Kawasan Perdagangan Bebas dan Pelabuhan Bebas Menjadi Undang-Undang Menjadi Undang-Undang

Peraturan Pemerintah Nomor 10 Tahun 2012 tentang Perlakuan Kepabeanan, Perpajakan dan Cukai Serta Tata Laksana Pemasukan dan Pengeluaran Barang Ke dan Dari Serta Berada di Kawasan Perdagangan Bebas dan Pelabuhan Bebas

Peraturan Pemerintah Nomor 41 Tahun 2021 tentang Penyelenggaraan Kawasan Perdagangan Bebas dan Pelabuhan Bebas

https://batam.tribunnews.com/2019/05/21/kronologis-pencabutan-cukai-rokok-mikol-di-4kawasan-ftz, diakses pada tanggal 10 Desember 2020. 